\title{
Glucosamine hydrochloride exerts a protective effect against unilateral ureteral obstruction-induced renal fibrosis by attenuating TGF- $\beta$ signaling
}

\author{
Jinah Park • So-Young Lee • Akira Ooshima • \\ Kyung-Min Yang • Jin Muk Kang • Young-Woong Kim • \\ Seong-Jin Kim
}

Received: 15 May 2013 /Revised: 11 August 2013 / Accepted: 4 September 2013 /Published online: 27 September 2013

(C) The Author(s) 2013. This article is published with open access at Springerlink.com

\begin{abstract}
Renal fibrosis is a common consequence of unilateral ureteral obstruction, which provides a useful model to investigate the pathogenesis of obstructive nephropathy and progressive renal fibrosis. Transforming growth factor (TGF- $\beta 1$ ) has been recognized as a key mediator in renal fibrosis by stimulating matrix-producing fibrogenic cells and promoting extracellular matrix deposition. Therefore, considerable efforts have been made to regulate TGF- $\beta$ signaling for antifibrotic therapy. Here, we investigated the mode of action of glucosamine hydrochloride (GS-HCl) on TGF- $\beta 1$-induced renal fibrosis. In the obstructed kidneys and TGF- $\beta 1$-treated renal cells, GS$\mathrm{HCl}$ significantly decreased renal expression of $\alpha$-smooth muscle actin, collagen I, and fibronectin. By investigating the inhibitory mechanism of GS-HCl on renal fibrosis, we found that GS-HCl suppressed TGF- $\beta$ signaling by inhibiting $N$-linked glycosylation of the type II TGF- $\beta$ receptor (T $\beta$ RII), leading to an inefficient trafficking of T $\beta$ RII to the membrane surface. Defective $N$-glycosylation of T $\beta$ RII
\end{abstract}

J. Park and S. Y. Lee contributed equally to the work.

Electronic supplementary material The online version of this article (doi:10.1007/s00109-013-1086-1) contains supplementary material, which is available to authorized users.

J. Park · S.-Y. Lee $\cdot$ A. Ooshima $\cdot$ K.-M. Yang $\cdot$ J. M. Kang $•$

Y.-W. Kim $\cdot$ S.-J. Kim $(\bowtie)$

CHA Cancer Institute, CHA University, 605 Yeoksam-dong,

Gangnam-gu, Seoul 135-081, South Korea

e-mail:kimsj@cha.ac.kr

S.-Y. Lee

Department of Internal Medicine, CHA Bundang Medical Center, CHA University, Seongnam, Korea

Y.-W. Kim

Department of Molecular Cardiology, Lerner Research Institute, Cleveland Clinic, Cleveland, OH, USA further suppressed the TGF- $\beta 1$-binding to T $\beta$ RII, thereby decreasing TGF- $\beta$ signaling. Notably, GS-HCl treatment significantly reduced TGF- $\beta 1$-induced up-regulation of Smad $2 /$ 3 phosphorylation and transcriptional activity in vivo and in vitro. Taken together, GS-HCl-mediated regulation of TGF- $\beta$ signaling exerted an antifibrotic effect, thereby ameliorating renal fibrosis. Our study suggests that GS-HCl would be a promising agent for therapeutic intervention for preventing TGF- $\beta 1$-induced renal fibrosis in kidney diseases.

\section{Key message}

- Glucosamine-mediated attenuation of TGF- $\beta$ signaling ameliorates renal fibrosis in vivo

- TGF- $\beta 1$-induced fibrogenic action is reduced by glucosamine in vitro

- $N$-glycosylation of the type II TGF- $\beta$ receptor is suppressed by glucosamine

- Glucosamine-induced defective $N$-glycosylation of T $\beta$ RII decreases TGF- $\beta$ signaling.

Keywords Renal fibrosis · Glucosamine hydrochloride . TGF- $\beta$ signaling $\cdot N$-glycosylation $\cdot$ Type II TGF- $\beta$ receptor

\section{Introduction}

Glucosamine is a common constituent of glycosaminoglycans in the cartilage matrix and synovial fluid [1]. It has been regarded as an anti-arthritis supplement due to its potential chondro-protective effects in osteoarthritis patients [2]. However, studies have also demonstrated the protective effect and anti-inflammatory feature of glucosamine hydrochloride (GS$\mathrm{HCl})$ on other diseases, including pulmonary inflammation and neurological deficits $[3,4]$. 
Renal fibrosis is a hallmark of chronic kidney disease and strongly correlates with deterioration of renal function. Under limited treatment options in the clinical setting, emerging evidences suggest targeted inhibition of signaling pathways involved in renal fibrosis as a promising therapeutic strategy for the treatment of fibrotic kidney diseases $[5,6]$.

In addition to its diverse regulations in normal physiological cellular processes and diseases [7], TGF- $\beta$ signaling has been shown to play a critical role as a potent fibrogenic inducer in renal fibrosis $[5,6]$. Evidences have indicated that TGF- $\beta 1$ induces renal fibrogenesis by activating interstitial fibroblasts, myofibroblasts, and tubule epithelial cells $[6,8]$ and increasing extracellular matrix proteins $[6,9]$. Moreover, studies have demonstrated the antifibrotic effects after blocking TGF- $\beta 1$ activities [10-13].

TGF- $\beta$ signaling is regulated by posttranslational modifications [14]. Dysregulation of posttranslational modifications may contribute to not only aberrant TGF- $\beta$ signaling, but also TGF- $\beta 1$-associated diseases. Considering that the binding of TGF- $\beta 1$ to the type II TGF- $\beta$ receptor (T $\beta$ RII) is the first step in TGF- $\beta$ signaling [15], it is particularly worthy to investigate the T $\beta$ RII biology. Recently, we have shown that $N$-glycosylation of T $\beta$ RII on its extracellular domain plays a crucial role in its cell surface transportation and ligand-binding affinity, thereby affecting downstream signaling [16].

Of note, it has been reported that GS-HCl exerts an inhibitory effect on $\mathrm{N}$-glycosylation of certain proteins, including epidermal growth factor receptor (EGFR) [17] and cyclooxygenase (COX)-2 [18], and modulates their functions by facilitating protein turnover or reducing phosphorylation. However, GS-HCl has not been precisely evaluated for its ability to influence $N$-glycosylation of T $\beta$ RII, a protein that may play a role in TGF- $\beta 1$-associated diseases by regulating TGF- $\beta$ signaling.

In this study, we demonstrated that $\mathrm{GS}-\mathrm{HCl}$ attenuated unilateral ureteral obstruction (UUO)-induced renal fibrosis in vivo and TGF- $\beta 1$-induced fibrogenic action in vitro. We also showed that GS-HCl decreased the elevated TGF- $\beta$ signaling in renal fibrosis. Further, we presented a mechanism that GS-HCl inhibited $N$-glycosylation of T $\beta$ RII, resulting in decreased TGF- $\beta$ signaling by preventing T $\beta$ RII proteins from being transported to the cell surface and subsequent binding with TGF- $\beta 1$.

\section{Materials and methods}

Establishment of UUO model and GS-HCl treatment

Male C57BL/6 mice were obtained from Orient Bio Inc. (Seongnam, South Korea). Five groups of mice $(n=5)$ were used for three separate experiments: (1) sham control, (2)
UUO + phosphate-buffered saline (PBS), (3) UUO + GS$\mathrm{HCl} 20 \mathrm{mg} / \mathrm{kg}$, (4) UUO + GS-HCl $40 \mathrm{mg} / \mathrm{kg}$, and (5) UUO $+\mathrm{GS}-\mathrm{HCl} 60 \mathrm{mg} / \mathrm{kg}$. UUO was performed as described previously [19]. GS-HCl (Sigma-Aldrich, St. Louis, MO) was dissolved in PBS and administered into mice via daily intraperitoneal injection with the indicated dose from 7 days prior to UUO surgery. All mice were sacrificed 14 days after UUO, and the kidney tissues were collected for various analyses. All procedures were conducted in accordance with guidelines provided by the CHA Hospital Animal Care and Use Committee.

Semiquantitative assessment of renal fibrosis

Kidney sections were prepared at 4- $\mu \mathrm{m}$ thickness and stained with Masson's trichrome for light microscopic examination. Four different randomly selected regions on the stained sections (three paraffin sections prepared from each kidney) were analyzed by BX43 Clinical Microscope (Olympus America Inc., Melville, NY). Fibrosis was graded by two independent pathologists. According to the Banff quantitative criteria for interstitial fibrosis [20], the extent of fibrosis in the renal cortical area up to 5,6 to 25,26 to 50 , and more than $50 \%$ was graded as score $0,1,2$, and 3 , respectively.

\section{RT-PCR and real-time RT-PCR}

Total RNA was extracted using TRIzol Reagent (Invitrogen, Carlsbad, CA), according to the manufacturer's instruction. PCR was carried out using AccuPower ${ }^{\mathrm{TM}}$ PCR PreMix Kit (Bioneer Co., Daejon, South Korea) with specific primer pairs. Quantitative real-time PCR was performed using Power SYBR Green PCR Master Mix (Applied Biosystems, Foster City, CA) on the $\mathrm{ViiA}^{\mathrm{TM}} 7$ Real-time PCR systems (Applied Biosystems). The mRNA levels of various genes were measured in triplicate and normalized with $18 \mathrm{~S}$. The sequences of the primer sets used in this study, including human/mouse collagen I, fibronectin, $\alpha$-smooth muscle actin ( $\alpha$-SMA), E-cadherin, TGF- $\beta 1$, connective tissue growth factor (CTGF), GAPDH, and $18 \mathrm{~S}$, are available upon request.

Immunofluorescence assay

HeLa, HKC- 8 cells, and tissues were incubated with the primary antibodies against Flag, protein disulfide isomerase (PDI), phalloidin, fibronectin, and $\alpha$-SMA. After incubation with secondary antibodies, cells and sections were assessed by the BX43 Clinical (IX51 Inverted) Microscope (Olympus America Inc.) or confocal laser scanning microscope (LSM510; Carl Zeiss, Jena, Germany). Details can be found in Supplementary methods online. 
Immunohistochemistry assay

Kidney sections were incubated with anti-phospho-Smad3 and anti-fibronectin. The sections were assessed by the BX43 Clinical Microscope (Olympus America Inc.). Details can be found in Supplementary methods online.

\section{Cell culture}

Human proximal tubular epithelial cells (HKC-8), human cervical adenocarcinoma cells (HeLa), and mouse primary renal epithelial cells were maintained in Dulbecco's modified Eagle's medium and Ham's F12 medium (DMEM/F12; Invitrogen) and DMEM (WelGENE, Daegu, South Korea). Details can be found in Supplementary methods online.

Transfection and treatment

HKC-8 and HeLa cells were transfected with FuGENE HD (Promega, Madison, WI), according to the manufacturer's instruction. Cells were treated with D-(+)-glucosamine hydrochloride and tunicamycin (Sigma-Aldrich). Cells were then treated with recombinant TGF- $\beta 1$ (R\&D Systems, Minneapolis, MN) in a serum-free condition. $N$-glycosylation was enzymatically removed from the denatured proteins in the extracts through incubation with PNGase F (New England Biolabs, Berverly, MA), according to the manufacturer's instruction.

\section{Western blot analysis}

Cells and tissues were prepared for immunoblot analysis with antibodies to Flag, phospho-Smad2, Smad2, phospho-Smad3, Smad3, fibronectin, $\alpha$-SMA, and $\beta$-actin. Details can be found in Supplementary methods online.

\section{Luciferase assay}

The luciferase activity was analyzed using the Luciferase Assay System kit (Promega), according to the manufacturer's protocol. Results were done in triplicate and normalized to $\beta$-gal activity. Details can be found in Supplementary methods online.

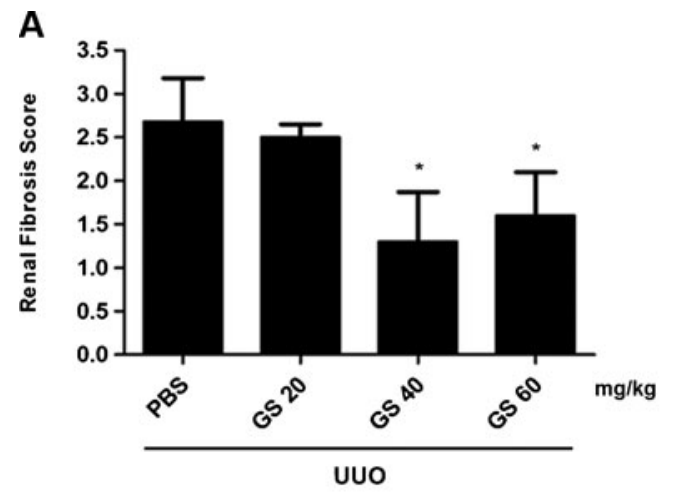

B

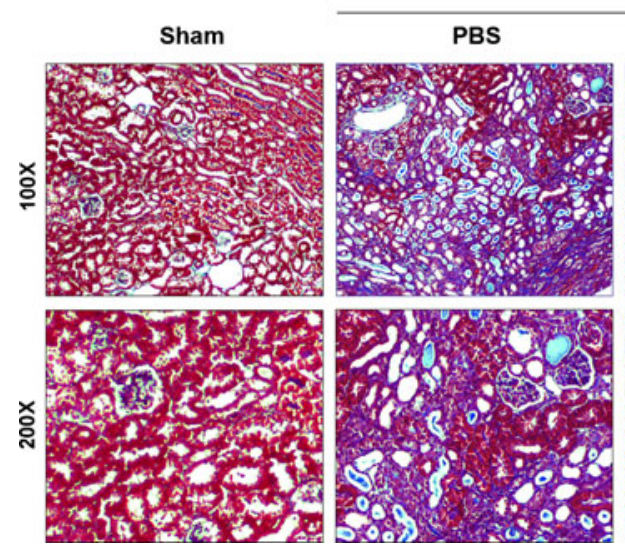

Fig. 1 GS-HCl exerts an antifibrotic effect in the UUO-induced renal fibrosis model. a Different doses of glucosamine hydrochloride were intraperitoneally injected into mice from 7 days prior to unilateral ureteral obstruction $(U U O)$ surgery. Kidney sections from various groups 14 days after UUO were subjected to Masson's trichrome staining. Semiquantitative assessment of renal fibrosis was performed with scores using a scale
UUO
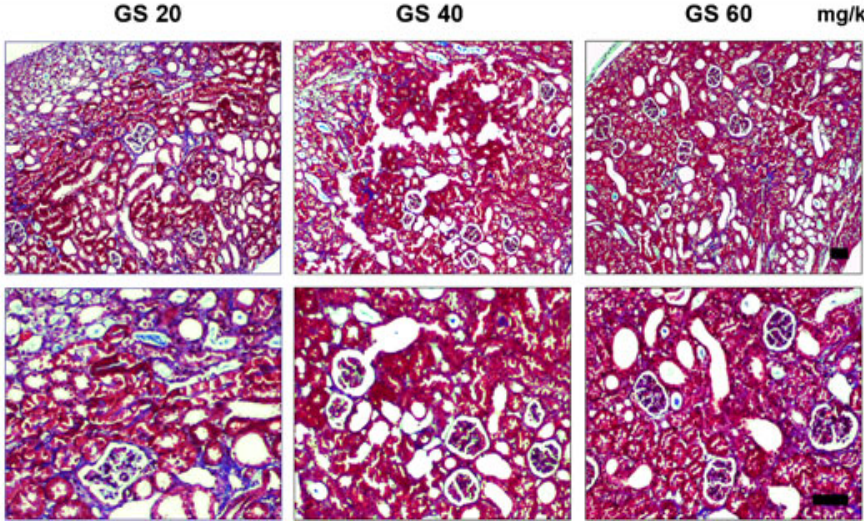

of 0 to 3 . Data are the mean \pm SEM of four random fields of three paraffin sections prepared from each kidney ( $n=5$ in each group). ${ }^{*} P<0.05$ versus PBS. b Representative photographs of the Masson's trichrome-stained sham, UUO, and GS-HCl-administered UUO mouse kidneys. Note that 40 and $60 \mathrm{mg} / \mathrm{kg}$ of GS- $\mathrm{HCl}$ significantly reduce renal fibrotic lesions after obstructive injury. Bar $=50 \mu \mathrm{m}$ 
A

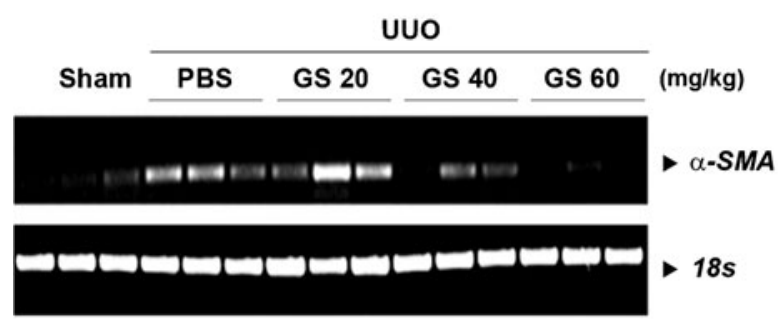

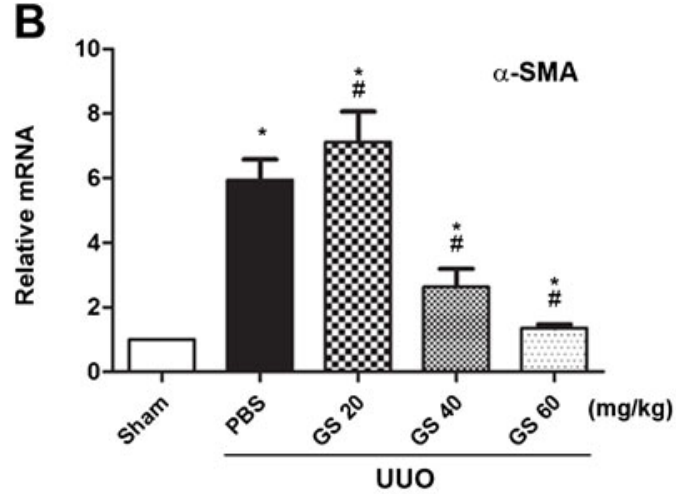

C

UUo
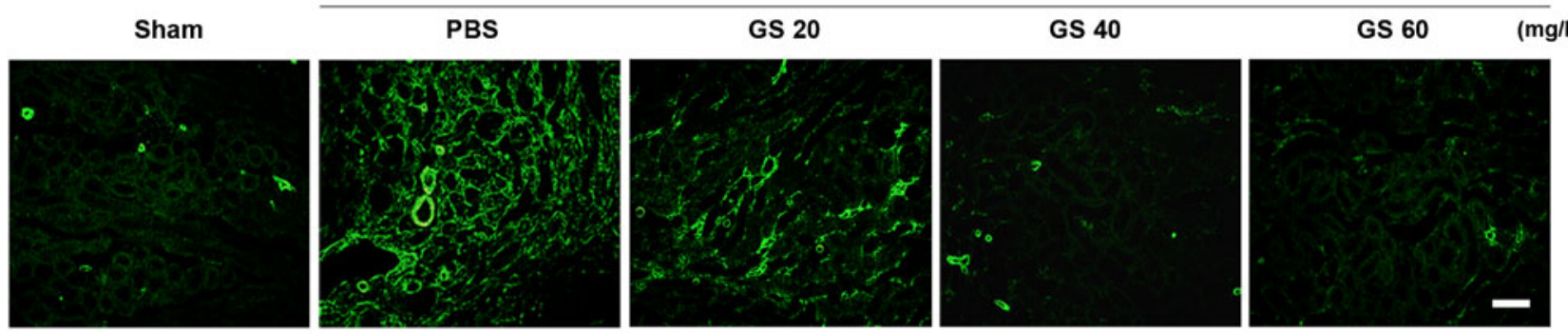

D

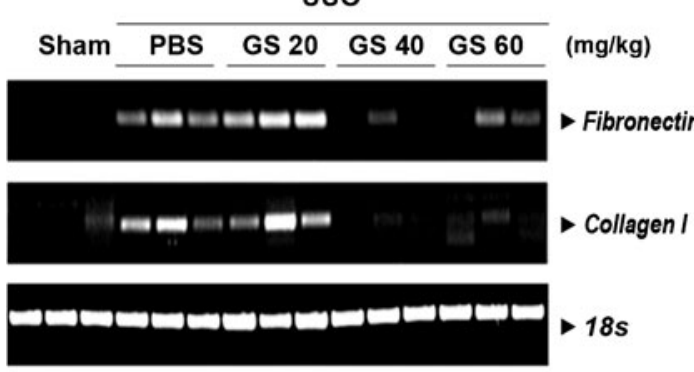

E

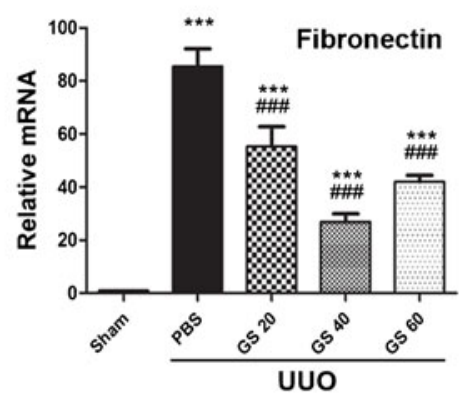

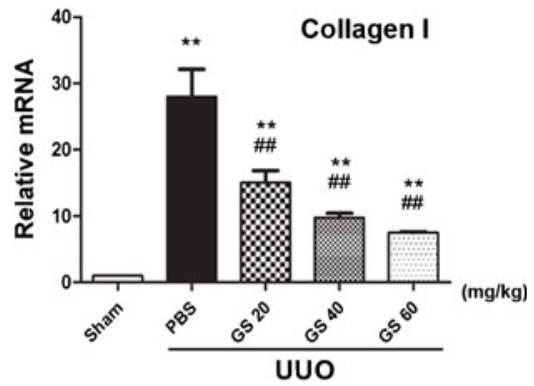

$\mathbf{F}$

UUO

Sham

GS 40

GS 60 $(\mathrm{mg} / \mathrm{kg})$
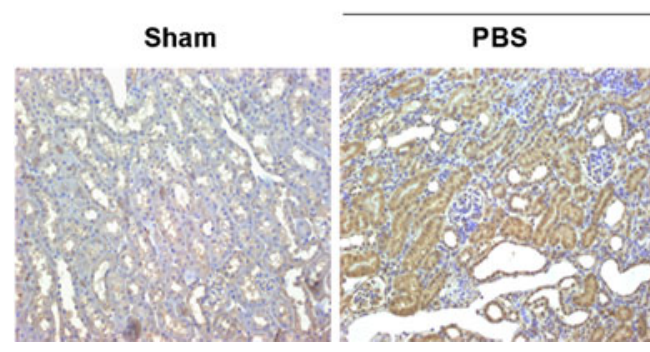

Fig. 2 GS- $\mathrm{HCl}$ decreases $\alpha$-SMA, collagen I, and fibronectin expression in the mouse model of UUO-induced renal fibrosis. a-f GS-HCl was daily administered into mice from 7 days prior to UUO. Kidneys were collected for various analyses 14 days after UUO. a Representative RTPCR and $\mathbf{b}$ quantitative real-time RT-PCR show that GS-HCl inhibits $\alpha$ smooth muscle actin $(\alpha-S M A)$ mRNA expression induced by UUO. ${ }^{*} P<$ 0.05 versus sham control; ${ }^{\#} P<0.05$ versus UUO + PBS. c Immunofluorescence staining for $\alpha$-SMA shows that $\mathrm{GS}-\mathrm{HCl}$ reduces expression of $\alpha$-SMA protein in the obstructed kidneys. $\mathbf{d}$ Representative RT-PCR and e quantitative real-time RT-PCR show that the elevated mRNA expression levels of collagen I and fibronectin by UUO are decreased by GS$\mathrm{HCl}$ administration. ${ }^{* * *} P<0.0001,{ }^{* *} P<0.001$ versus sham control; ${ }^{\# \#} P<0.0001,{ }^{\# \#} P<0.001$ versus UUO + PBS. f Immunohistochemical staining for fibronectin shows that $\mathrm{GS}-\mathrm{HCl}$ reduces overdeposition of fibronectin protein in the obstructed kidneys. a, b, d, e Data are the mean \pm SEM of three independent measurements. $\mathbf{c}-\mathbf{f}$ Representative photomicrographs of immunostaining were obtained from evaluating four random fields of each kidney ( $n=5$ in each group). Bar $=50 \mu \mathrm{m}$ 
Flow cytometry

The numbers of biotinylated TGF- $\beta 1$-bound T $\beta$ RII molecules were quantified using biotinylated human TGF- $\beta 1$ (R\&D Systems), according to the manufacturer's instructions. Before flow cytometric analysis, cells were treated with 7-amino-actinmycin D (BD PharMingen, Bedford, MA) to exclude dead cells. Details can be found in Supplementary methods online.

Statistical analysis

Data obtained from this study are expressed as the mean \pm SEM. Statistical analyses of data were performed by using SPSS Program for Windows (ver. 17; SPSS Inc., Chicago, IL). Comparison between groups was made with one-way
ANOVA, followed by the Student-Newman-Keuls test. Significance was achieved at $P<0.05$.

\section{Results}

GS-HCl ameliorates renal fibrosis in obstructive nephropathy

We assessed the effect of $\mathrm{GS}-\mathrm{HCl}$ on renal fibrosis after injury in vivo. Starting 7 days prior to UUO surgery, we administered $\mathrm{GS}-\mathrm{HCl}$ daily into mice via intraperitoneal injection in dosages of 20, 40, and $60 \mathrm{mg} / \mathrm{kg}$. Semiquantitative determination 14 days after UUO surgery revealed significantly lower fibrosis score in the obstructed kidneys treated with $\mathrm{GS}-\mathrm{HCl}$ (40 and $60 \mathrm{mg} / \mathrm{kg}$ ) than those treated with PBS (Fig. 1a). Histological examination showed

A
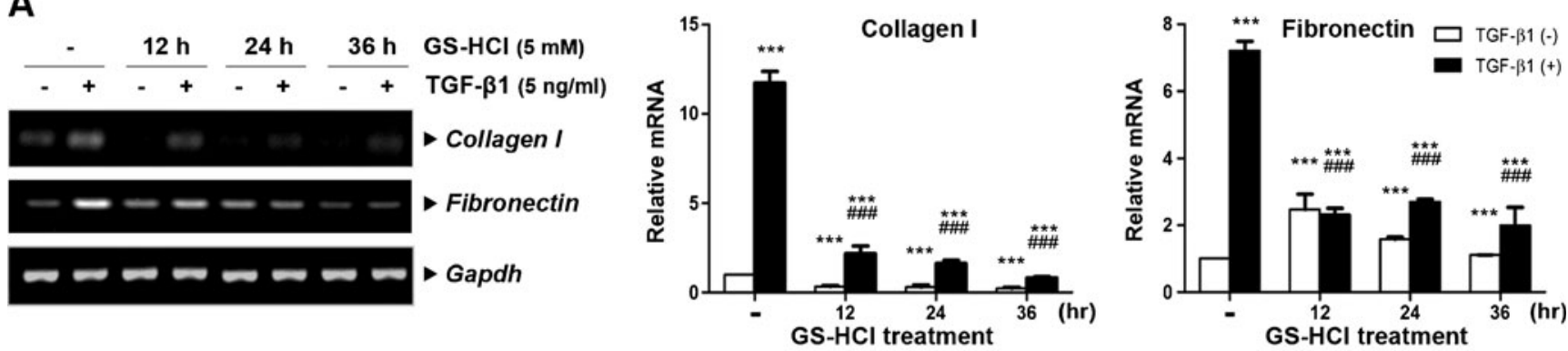

B
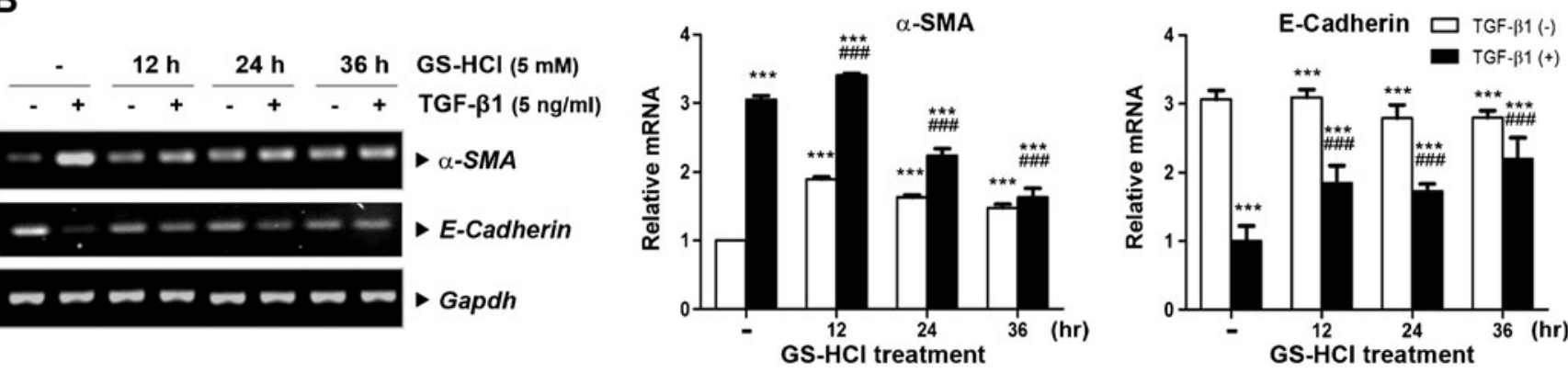

C
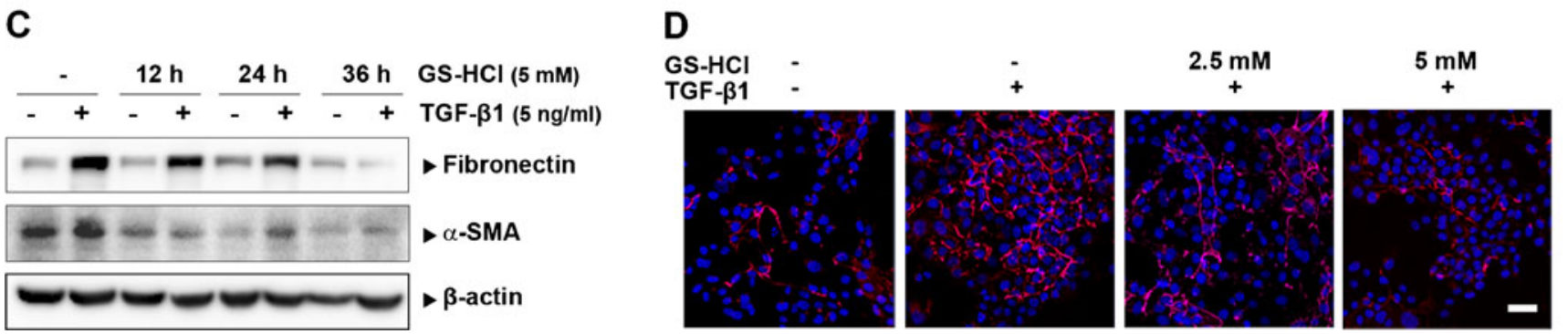

Fig. 3 GS-HCl diminishes TGF- $\beta 1$-induced fibrogenic responses in renal epithelial cells. a-d HKC-8 cells were treated with $5 \mathrm{mM}$ of GS$\mathrm{HCl}$ for various time intervals. Cells were then incubated with TGF- $\beta 1$ ( $3 \mathrm{ng} / \mathrm{ml}$ for $16 \mathrm{~h}$ ) in a serum-free condition. a, b Representative RT-PCR and quantitative RT-PCR data show that GS-HCl inhibits TGF- $\beta 1$-induced collagen I, fibronectin, and $\alpha$-SMA mRNA expression, while blocking TGF- $\beta 1$-mediated suppression of E-cadherin expression. Data are the mean \pm SEM of three independent measurements. ${ }^{* * *} P<0.0001$

versus control without TGF- $\beta 1$; ${ }^{\# \# \#} P<0.0001$ versus control with TGF- $\beta 1$. c Cell lysates were immunoblotted with antibodies to fibronectin, $\alpha$-SMA, and $\beta$-actin. Note that GS-HCl decreases protein expression of TGF- $\beta 1$-induced fibronectin and $\alpha$-SMA. d Immunofluorescence staining was performed with fibronectin antibody. DAPI, 4',6diamidino-2-phenylindole, was used for nucleus staining (blue). Note that $\mathrm{GS}-\mathrm{HCl}$ reduces protein expression of TGF- $\beta 1$-induced fibronectin. Bar $=50 \mu \mathrm{m}$ 
obvious interstitial fibrosis, as shown by strong collagen deposition, in the obstructed kidneys (Fig. 1b). However, the obstructed kidneys treated with 40 and $60 \mathrm{mg} / \mathrm{kg}$ of $\mathrm{GS}-\mathrm{HCl}$ displayed minimal interstitial fibrosis. As illustrated by these results, GS-HCl demonstrates its ability to prevent UUO-induced renal fibrosis in vivo.

GS-HCl reduces $\alpha$-SMA expression and ECM induction in obstructive nephropathy

Activation of $\alpha$-SMA-positive and matrix-producing myofibroblasts is a distinctive feature of renal fibrosis induced by UUO $[5,9]$. TGF- $\beta 1$ stimulates interstitial fibroblasts and tubular epithelial cells to undergo myofibroblastic activation, thus rendering them into matrix-producing fibrogenic cells [5]. To explore whether GS-HCl regulated $\alpha$-SMA expression in UUO-induced renal fibrosis, we examined the expression level of $\alpha$ SMA in the sham-operated, UUO-, and GS-HCl-treated UUO kidneys. The mRNA expression of $\alpha$-SMA was barely detectable in the sham-operated kidneys (Fig. 2a, b). Immunofluorescence staining also showed positive staining only in the smooth muscle layer of the blood vessels in the sham-operated kidneys (Fig. 2c). In contrast, UUO led to the dramatic up-regulation of $\alpha$-SMA in the obstructed kidneys. However, $\alpha$-SMA induction was markedly reduced by treatment with 40 and $60 \mathrm{mg} / \mathrm{kg}$ of GS-HCl. These data suggest that GS-HCl exhibits potential to reduce $\alpha$-SMA-positive myofibroblast activation during renal fibrosis.

We further investigated whether GS-HCl reduced the increase of extracellular matrix (ECM) deposition in the UUO kidney. GS-HCl effectively inhibited mRNA expression level of major interstitial matrix components, including fibronectin and collagen I, which were elevated after obstructive injury (Fig 2d, e). Immunohistochemical staining produced a similar result of significant decrease of fibronectin in the GS-HCl-treated UUO kidneys (Fig. 2f). As demonstrated by these findings, GS-HCl exerts an inhibitory effect against ECM overproduction and deposition in the obstructed kidney.

GS-HCl reduces TGF- $\beta 1$-induced fibrogenic effects in renal epithelial cells

Next, we studied the inhibitory effect of GS-HCl on TGF- $\beta 1$ induced fibrogenic action in renal epithelial cells. TGF- $\beta 1$ induced mRNA expression of ECM components, including collagen I and fibronectin, in human kidney tubular epithelial cells (HKC-8) (Fig. 3a). However, GS-HCl significantly suppressed TGF- $\beta 1$-induced collagen I and fibronectin, as demonstrated by RT-PCR and quantitative real-time RT-PCR analyses. TGF- $\beta 1$ also mediated a myofibroblast phenotype
Fig. 4 GS-HCl reduces TGF- $\beta$ signaling in the obstructive mouse kidneys and renal epithelial cells. a, b Different doses of GS-HCl were intraperitoneally injected into mice from 7 days prior to UUO surgery. Fourteen days after UUO, a tissue homogenates were immunoblotted with phospho-Smad3 and Smad3. Note that elevated Smad3 phosphorylation induced by UUO was significantly decreased by GS$\mathrm{HCl}$ administration. b Immunohistochemical stainings for phospho$\mathrm{Smad} 3$ in the kidney sections. Note that GS-HCl reduces the Smad3 phosphorylation level elevated by UUO. Representative photomicrographs of immunohistochemical staining were obtained from analyzing four random fields of each kidney ( $n=5$ in each group). $B a r=50 \mu \mathrm{m}$. c, d HKC-8 cells and e mouse primary kidney epithelial cells were treated with $\mathrm{GS}-\mathrm{HCl}$ with the indicated doses for the indicated periods of time. Cells were then incubated with TGF- $\beta 1(5 \mathrm{ng} / \mathrm{ml}$ for $30 \mathrm{~min}$ ) in a serum-free condition. Cell lysates were immunoblotted with anti-phospho-Smad2/3, anti-Smad $2 / 3$, and $\beta$-actin. Band intensities representing $\mathrm{pSmad} 2 / 3$ and $\mathrm{Smad} 2 / 3$ expression levels were converted by densitometry using ImageJ software into the ratio of $\mathrm{pSmad} 2 / 3$ to $\mathrm{Smad} 2 / 3$. Note that GS-HCl suppresses phosphorylation of Smad2 and $\mathrm{Smad} 3$. f $(\mathrm{CAGA})_{12}$-luciferase reporter and $\beta$-gal were transfected into HKC-8 cells. After GS-HCl $(24 \mathrm{~h})$ and tunicamycin $(T N ; 12 \mathrm{~h})$ treatment, cells were treated with TGF- $\beta 1$ at $3 \mathrm{ng} / \mathrm{ml}$ for $16 \mathrm{~h}$ in a serum-free condition. Luciferase activity was normalized with $\beta$-gal activity. Note that GS-HCl significantly decreases TGF- $\beta 1$-induced luciferase activity. ${ }^{* * *} P<0.0001,{ }^{* *} P<0.001$ versus control without TGF- $\beta 1$; ${ }^{\# \#} P<0.001$ versus control with TGF- $\beta 1$

by inducing $\alpha$-SMA gene expression (Fig. 3b). In addition, HKC-8 cells demonstrated loss of epithelial characteristics upon TGF- $\beta 1$ treatment by decreasing the mRNA expression of E-cadherin. On the other hand, GS-HCl reduced TGF- $\beta$ 1mediated $\alpha$-SMA gene induction and blocked the suppression of E-cadherin expression by TGF- $\beta 1$. Consistently, GS-HCl treatment decreased the expression of fibronectin and $\alpha$-SMA proteins induced by TGF- $\beta 1$ (Fig. 3c). Furthermore, immunofluorescence staining revealed an evident reduction of TGF- $\beta 1$-induced fibronectin expression after GS-HCl treatment (Fig. 3d). Taken together, these data suggest that GS$\mathrm{HCl}$ effectively diminishes TGF- $\beta 1$-mediated fibrogenic effects in renal epithelial cells.

\section{GS- $\mathrm{HCl}$ attenuates TGF- $\beta$ signaling in vivo and in vitro}

In order to explore whether GS-HCl influenced TGF- $\beta$ signaling in the obstructed kidney, we next analyzed the phosphorylation level of Smad3 proteins, which played a major role in renal fibrosis in the downstream of TGF- $\beta$ signaling [15] in an in vivo model of obstructive nephropathy. GS- $\mathrm{HCl}$ administration significantly reduced elevated Smad3 phosphorylation level in the obstructed kidneys (Fig. $4 a, b$ ), implying its ability to attenuate TGF- $\beta$ signaling in renal fibrosis in vivo. To further address the physiological significance of GS-HCl on TGF- $\beta$ signaling in vitro, we treated GS- $\mathrm{HCl}$ in a dose- and time-dependent manner into the HKC-8 cells and analyzed the phosphorylation levels of Smad 2 and Smad3 proteins after TGF- $\beta 1$ stimulation. GS-HCl treatment markedly reduced Smad2/3 

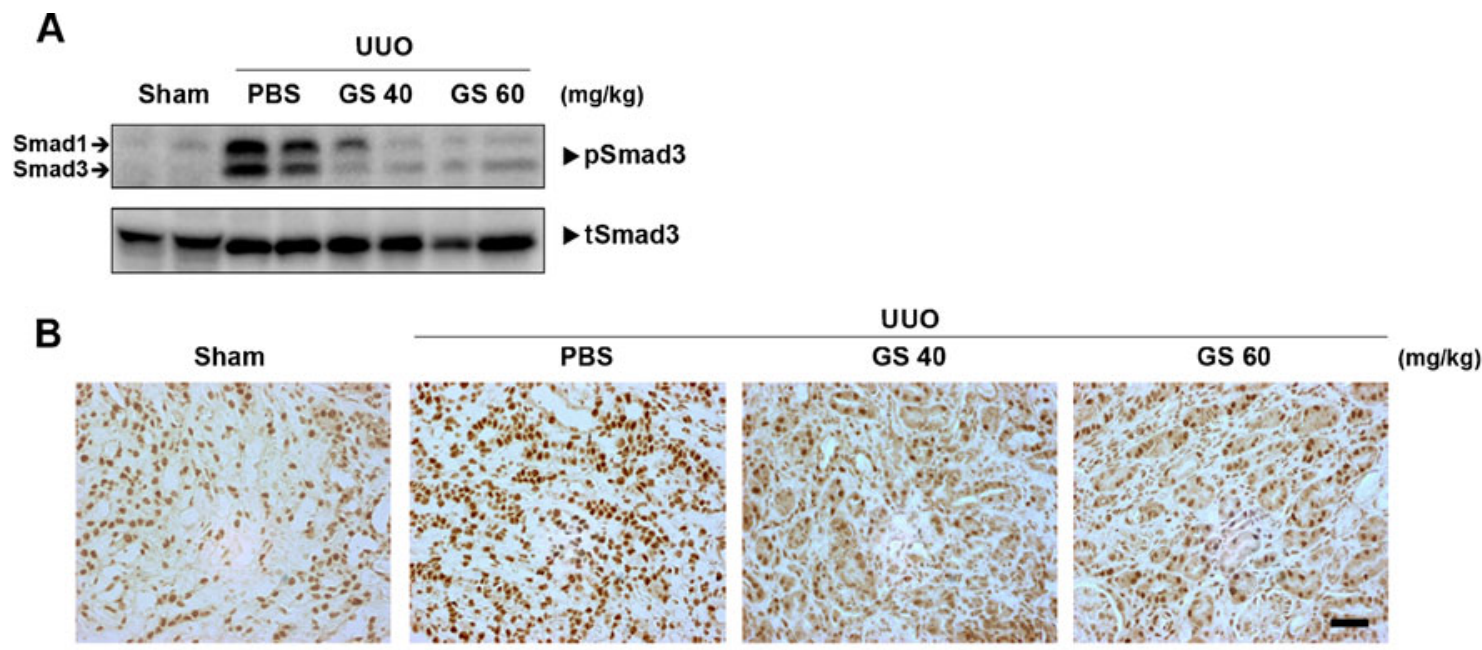

\section{HKC-8 Cells}

D HKC-8 Cells

E Primary Kidney Epithelial Cells

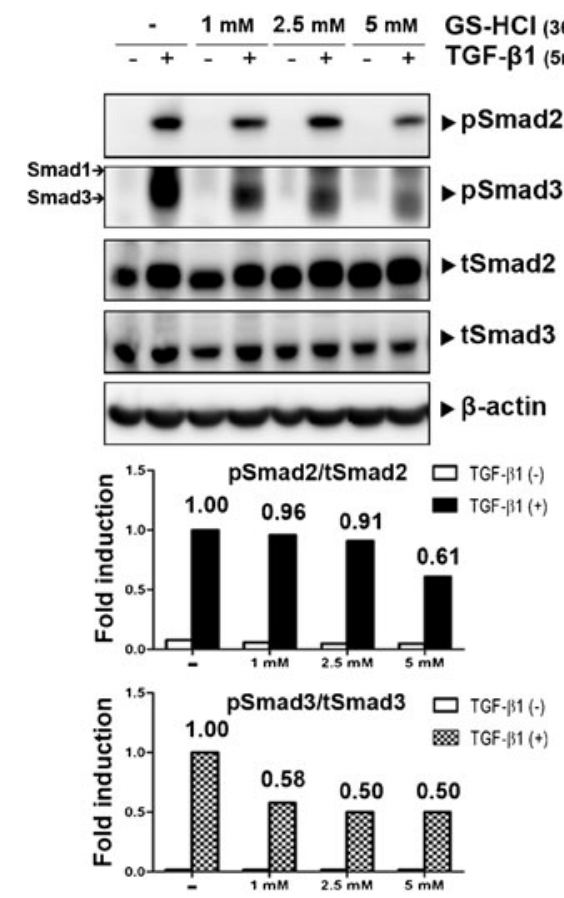

$\frac{-}{-+} \frac{12 \mathrm{~h}}{-+} \frac{24 \mathrm{~h}}{-+} \frac{36 \mathrm{~h}}{-+} \operatorname{GS}-\mathrm{HCCl}(5 \mathrm{mM})$ $\frac{-}{-+} \frac{12 \mathrm{~h}}{-+} \frac{24 \mathrm{~h}}{-+} \frac{36 \mathrm{~h}}{-+} \underset{\operatorname{TGF}-\beta 1}{\operatorname{GS}-\mathrm{HCl}_{(5 \mathrm{mg} / \mathrm{ml})}}$
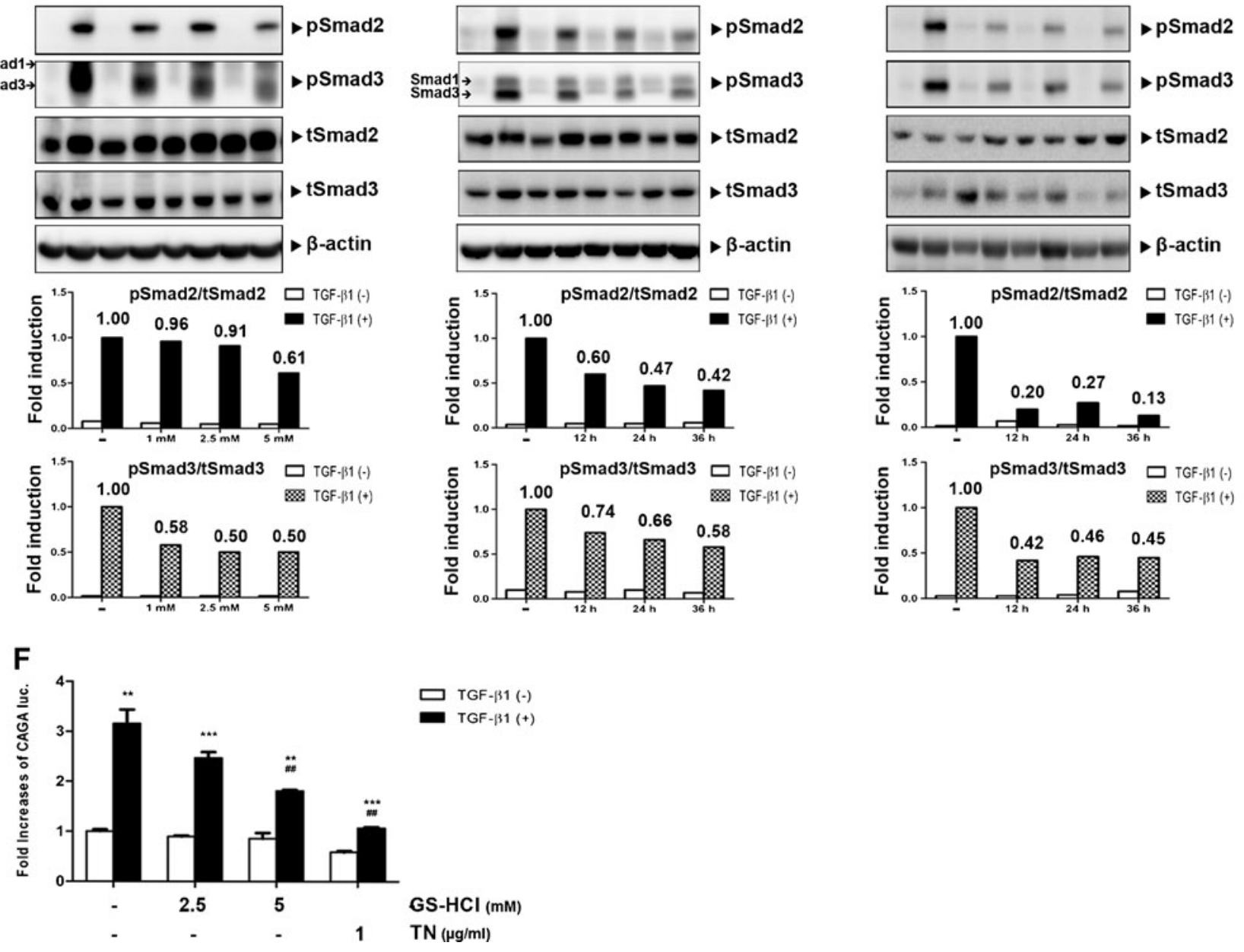

phosphorylation in a dose- and time-dependent fashion (Fig. 4c, d). Dramatic decrease of Smad2/3 phosphorylation upon $\mathrm{GS}-\mathrm{HCl}$ treatment was also shown in mouse primary kidney epithelial cells (Fig. 4e). We further observed that GS-HCl attenuated TGF- $\beta$-induced Smad3driven CAGA transcriptional activity in a dose-dependent manner (Fig. 4f). Collectively, these data demonstrate that GS-HCl effectively attenuates TGF- $\beta$ signaling. 
GS-HCl inhibits $N$-glycosylation of T $\beta \mathrm{RII}$ and decreases TGF- $\beta$ signaling

Previous reports demonstrated that GS-HCl exerted an inhibitory effect on $N$-glycosylation of certain proteins $[17,18$, 21-23]. Furthermore, $N$-glycosylation level of T $\beta$ RII was found to determine TGF- $\beta$ sensitivity [16]. Therefore, we hypothesized that GS-HCl reduced TGF- $\beta$ signaling by inhibiting $N$-glycosylation of T $\beta$ RII. To investigate whether GS-HCl influenced $N$-glycosylation of T $\beta$ RII, we treated GS$\mathrm{HCl}$ to HKC-8 cells transfected with T $\beta \mathrm{RII}$. Western blot analysis on the expression patterns of T $\beta$ RII showed multibands of high molecular weight over $\sim 72 \mathrm{kDa}$ (Fig. 5a). To confirm that the upper bands were produced by $N$-glycosylation of T $\beta$ RII, we introduced tunicamycin, a potent inhibitor of $N$-glycosylation which blocks the synthesis of $N$-glycans, and PNGase $\mathrm{F}$ which eliminates all $N$-glycans from T $\beta$ RII. Only a single band at $\sim 64 \mathrm{kDa}$ was detected upon tunicamycin and PNGase F treatment, indicating that the upper bands of T $\beta$ RII were associated with $N$-glycosylation of T $\beta$ RII. GS$\mathrm{HCl}$ treatment significantly decreased T $\beta \mathrm{RII}$ expression at higher molecular weights in a dose-dependent manner. It also led to the accumulation of T $\beta$ RII at lower molecular weights in the range between $\sim 68$ and $\sim 64 \mathrm{kDa}$. This result suggested that most T $\beta$ RII proteins were impeded by GS-HCl from being $N$-glycosylated, while a small portion was still $N$ glycosylated. Collectively, these data indicate that GS-HCl effectively disrupts $N$-glycosylation of T $\beta$ RII.

To examine the role of GS-HCl-induced defective $N$-glycosylation of T $\beta$ RII in TGF- $\beta$ signaling, we treated GS-HCl into HKC-8 cells overexpressing with T $\beta$ RII and analyzed Smad $2 / 3$ phosphorylation after TGF- $\beta 1$ stimulation. Indeed, GS-HCl treatment reduced Smad2/3 phosphorylation in a dose-dependent fashion. Also, the expression patterns of defectively $N$-glycosylated T $\beta$ RII proteins corresponded to the decrease of Smad2/3 phosphorylation (Fig. 5b). The

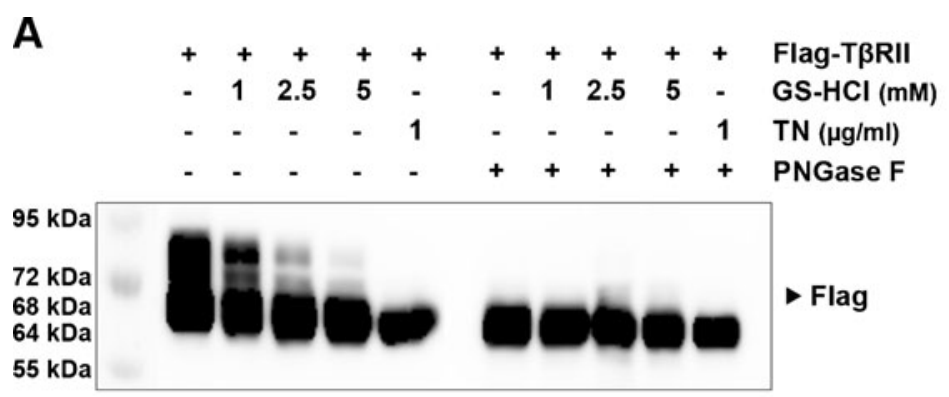

B

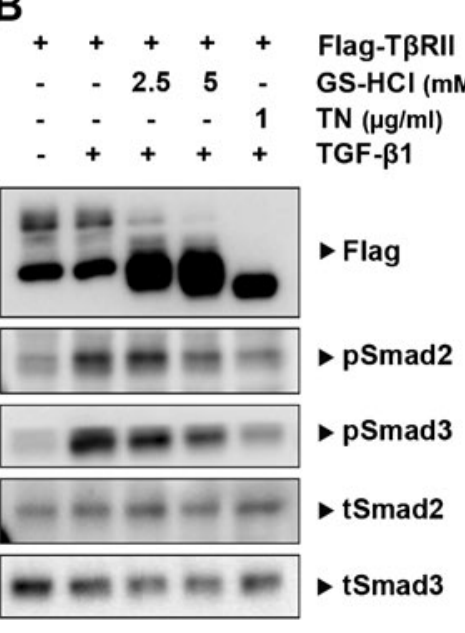

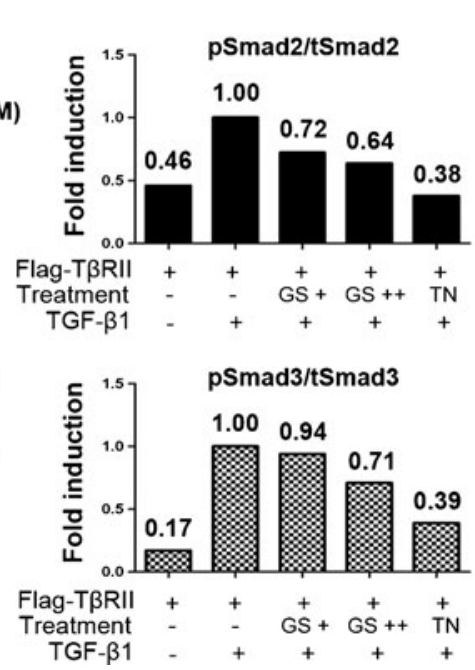

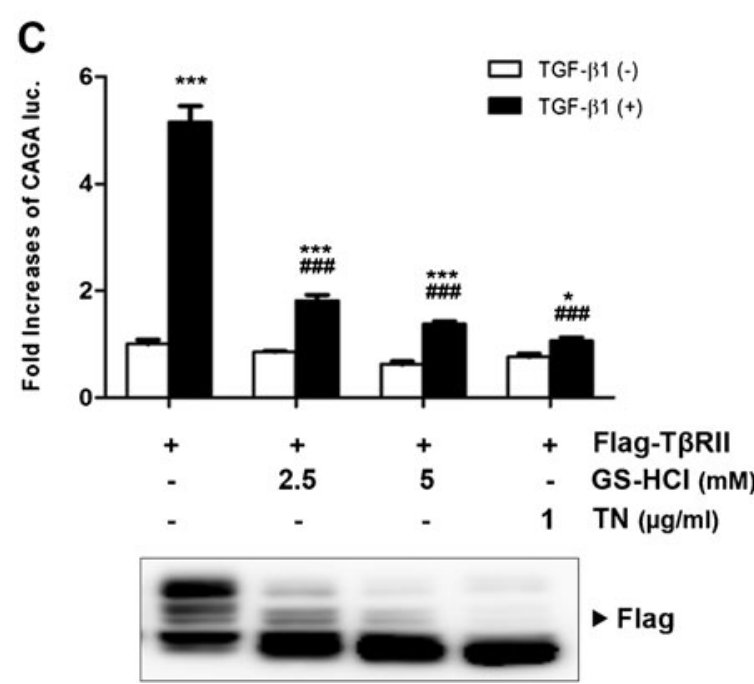

Smad $2 / 3$ expression levels were converted by densitometry using ImageJ software into the ratio of $\mathrm{pSmad} 2 / 3$ to Smad2/3. Note that GS-HCl suppresses phosphorylation of Smad 2 and $\mathrm{Smad} 3$ as well as $N$-glycosylation of T $\beta$ RII. $\mathbf{c}(\mathrm{CAGA})_{12}$-luciferase reporter and $\beta$-gal were cotransfected with Flag-T $\beta$ RII into HKC-8 cells. After GS-HCl (24 h) and TN (12 h) treatment, cells were treated with TGF- $\beta 1$ at $3 \mathrm{ng} / \mathrm{ml}$ for $16 \mathrm{~h}$ in a serum-free condition. Luciferase activity was normalized with $\beta$-gal activity. Note that GS-HCl significantly decreases TGF- $\beta 1$-induced luciferase activity. ${ }^{* * *} P<0.0001,{ }^{*} P<0.05$ versus control without TGF- $\beta 1 ;{ }^{\# \#+1} P<0.0001$ versus control with TGF- $\beta 1$ 
inhibitory effect of GS-HCl on TGF- $\beta$ signaling was further demonstrated by decreased TGF- $\beta 1$-induced transcriptional activity in a dose-dependent manner (Fig. 5c). Taken together, these data suggest that $\mathrm{GS}-\mathrm{HCl}$ inhibits $N$-glycosylation of $\mathrm{T} \beta \mathrm{RII}$ and subsequently reduces TGF- $\beta$ signaling.

GS-HCl-induced defective $N$-glycosylation of T $\beta$ RII controls cell surface transport of T $\beta$ RII and TGF- $\beta 1$-binding to T $\beta$ RII

$N$-glycosylation is involved in cell surface transport of membrane proteins, including TGF- $\beta$ receptors $[16,24]$. To investigate the effect of GS-HCl-induced defective $N$-glycosylation of T $\beta$ RII on its cell surface transport, we performed immunofluorescence assay to observe the subcellular localization of T $\beta$ RII transiently overexpressed in HeLa cells. T $\beta$ RII proteins were localized on the membrane surface almost merging with phalloidin, which stains actin filaments for observing cell morphology (Fig. 6a). However, many portions of GS-HCltreated T $\beta$ RII were not able to be successfully transported to the cell surface. Instead, they were predominantly accumulated in the cytosol merging with PDI, an endoplasmic reticulum (ER) marker (Fig. 6b). Their localization was comparable to that of aglycosylated T $\beta$ RII under the tunicamycin effect. These findings demonstrate that $\mathrm{GS}-\mathrm{HCl}$ hinders cell surface transport of T $\beta$ RII. Further, the ability of TGF- $\beta 1$ to bind to untreated or GS-HCl-treated T $\beta$ RII was evaluated with biotinylated TGF- $\beta 1$ in HKC-8 cells using flow cytometry (Fig. 6c). The TGF- $\beta 1$-binding in the PBS-treated cells was significantly increased in a dose-dependent manner. However, GS-HCl treatment dramatically reduced the binding of TGF- $\beta 1$ to T $\beta$ RII. This result might be explained by the inability of GS-HCl-treated T $\beta$ RII to be successfully transported to the cell surface. We also observed that GS$\mathrm{HCl}$ reduced the TGF- $\beta 1$-binding to $\mathrm{T} \beta \mathrm{RII}$ overexpressed in HKC-8 cells (Supplementary Fig. 1). Therefore, these findings indicate that $\mathrm{GS}-\mathrm{HCl}$ impedes $N$-glycosylation of $\mathrm{T} \beta \mathrm{RII}$, thereby inhibiting cell surface transport of $\mathrm{T} \beta \mathrm{RII}$ and suppressing subsequent TGF- $\beta 1$-binding.

\section{Discussion}

Renal fibrosis is a common manifestation of chronic kidney disease. It is widely recognized that TGF- $\beta /$ Smad signaling plays an essential role in fibrogenesis. Therefore, regulation of TGF- $\beta$ signaling is considered a promising therapeutic option for the treatment of renal disease [6]. Evidences show that inhibition of TGF- $\beta$ signaling by neutralizing TGF- $\beta 1$ antibodies or soluble TGF- $\beta$ receptor ameliorates renal fibrosis in vivo and in vitro $[10-13,25]$. Particularly, the administration of TGF- $\beta$ receptor kinase inhibitors, such as IN-1130 and GW788388, has been shown to decrease renal fibrosis by regulating receptor function $[10,11]$. Likewise, regulation of
T $\beta$ RII could be worthy of examination, since the binding of TGF- $\beta 1$ to T $\beta$ RII is the first critical step in TGF- $\beta$ signal transduction.

TGF- $\beta$ signaling mediates renal fibrosis by stimulating overproduction of ECM proteins [6, 9] and inducing transformation of tubular epithelial cells to myofibroblasts through epithelial-mesenchymal transition [8]. Thus, renal epithelial cells and kidney tissues undergoing renal fibrosis often exhibit significantly increased expression of $\alpha$-SMA and interstitial matrix components, such as collagen and fibronectin. Our data showed that GS-HCl effectively inhibited up-regulation of $\alpha$ SMA, collagen I, and fibronectin in the TGF- $\beta 1$-treated renal epithelial cells (Fig. 3) and mouse UUO kidneys (Fig. 2), thereby leading to amelioration of renal fibrosis (Fig. 1). Collectively, our in vitro and in vivo data demonstrate the antifibrotic effect of $\mathrm{GS}-\mathrm{HCl}$ on renal fibrosis. To investigate more whether $\mathrm{GS}-\mathrm{HCl}$ influenced the synthesis of cytokines mediating renal fibrosis, we particularly measured TGF- $\beta 1$ and CTGF expression. As a well-known fibrogenic growth factor, CTGF is induced by TGF- $\beta 1$, followed by ECM production [26]. As shown in Supplementary Fig. 2a, UUO up-regulated TGF- $\beta 1$ and CTGF mRNA expression. While mRNA expression of TGF- $\beta 1$ was not affected, CTGF was significantly reduced by $\mathrm{GS}-\mathrm{HCl}$ administration in the obstructive kidneys. Western blot analysis also showed that active dimeric TGF- $\beta 1$ ( $25 \mathrm{kDa})$ was up-regulated by UUO, but not reduced by GS-HCl (Supplementary Fig. 2b). These results indicate that $\mathrm{GS}-\mathrm{HCl}$ may reduce $\mathrm{TGF}-\beta 1$-induced fibrogenic actions by attenuating TGF- $\beta$ signaling, rather than by decreasing TGF- $\beta 1$ production.

Next, we further addressed that GS-HCl-mediated antifibrotic effects were associated with GS-HCl-induced attenuation of TGF- $\beta$ signaling. T $\beta$ RII is $N$-glycosylated on its extracellular domain [27], and we observed that TGF- $\beta$ sensitivity was determined by different maturation levels of $N$ glycosylation of T $\beta \mathrm{RII}[16]$. And, $\mathrm{GS}-\mathrm{HCl}$ induced functional defects of certain proteins, including apoB-100 [21], furin [22], ICAM-1 [23], EGFR [17], and COX-2 [18], by modulating their $N$-glycosylation. Through our examination, we observed that GS-HCl also impeded $N$-glycosylation of TßRII (Fig. 5). According to our previous study on the $N$ glycosylation of T $\beta$ RII [16], the upper bands of T $\beta$ RII $(>$ $\sim 72 \mathrm{kDa}$ ) indicate more processed types of $N$-glycosylated T $\beta$ RII, indicating hybrid or complex types. On the other hand, the lower bands of T $\beta$ RII $(\sim 68 \mathrm{kDa})$ represent the T $\beta$ RII undergoing core $N$-glycosylation to which unprocessed high-mannose $N$-glycans are attached. Also, aglycosylated T $\beta$ RII under the tunicamycin effect was detected around a molecular weight of $\sim 64 \mathrm{kDa}$. GS- $\mathrm{HCl}$ inhibited $N$-glycosylation of most T $\beta$ RII proteins. Yet, T $\beta$ RII proteins that escaped the GS-HCl effect were still $N$-glycosylated. GS-HCl further prevented successful trafficking of T $\beta$ RII to the cell surface membrane, thus weakening the interaction between 
A
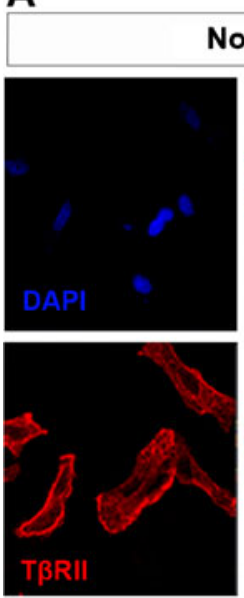
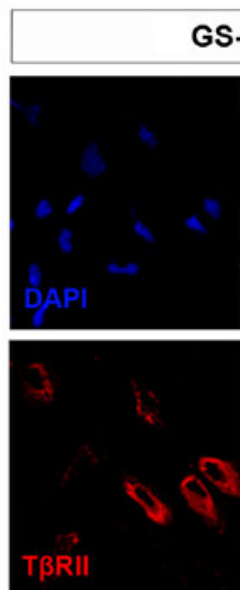

GS-HCl
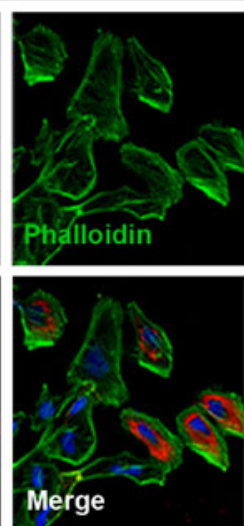
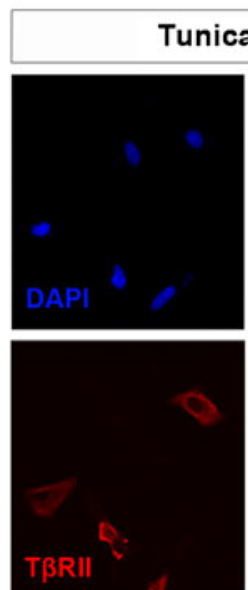

unicamycin
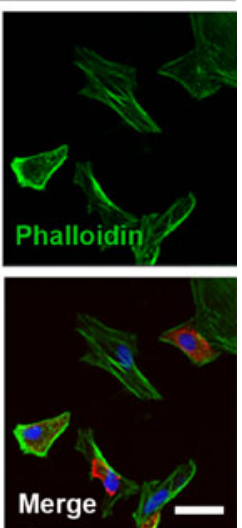

B

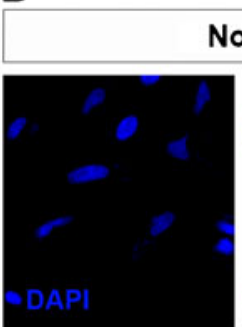

None
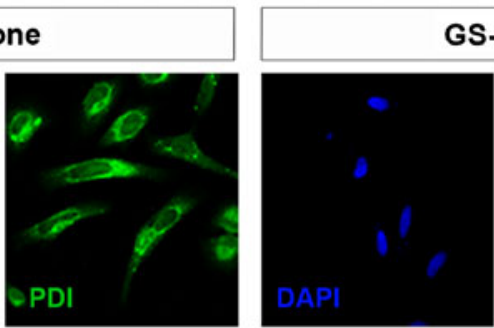

GS-HCl
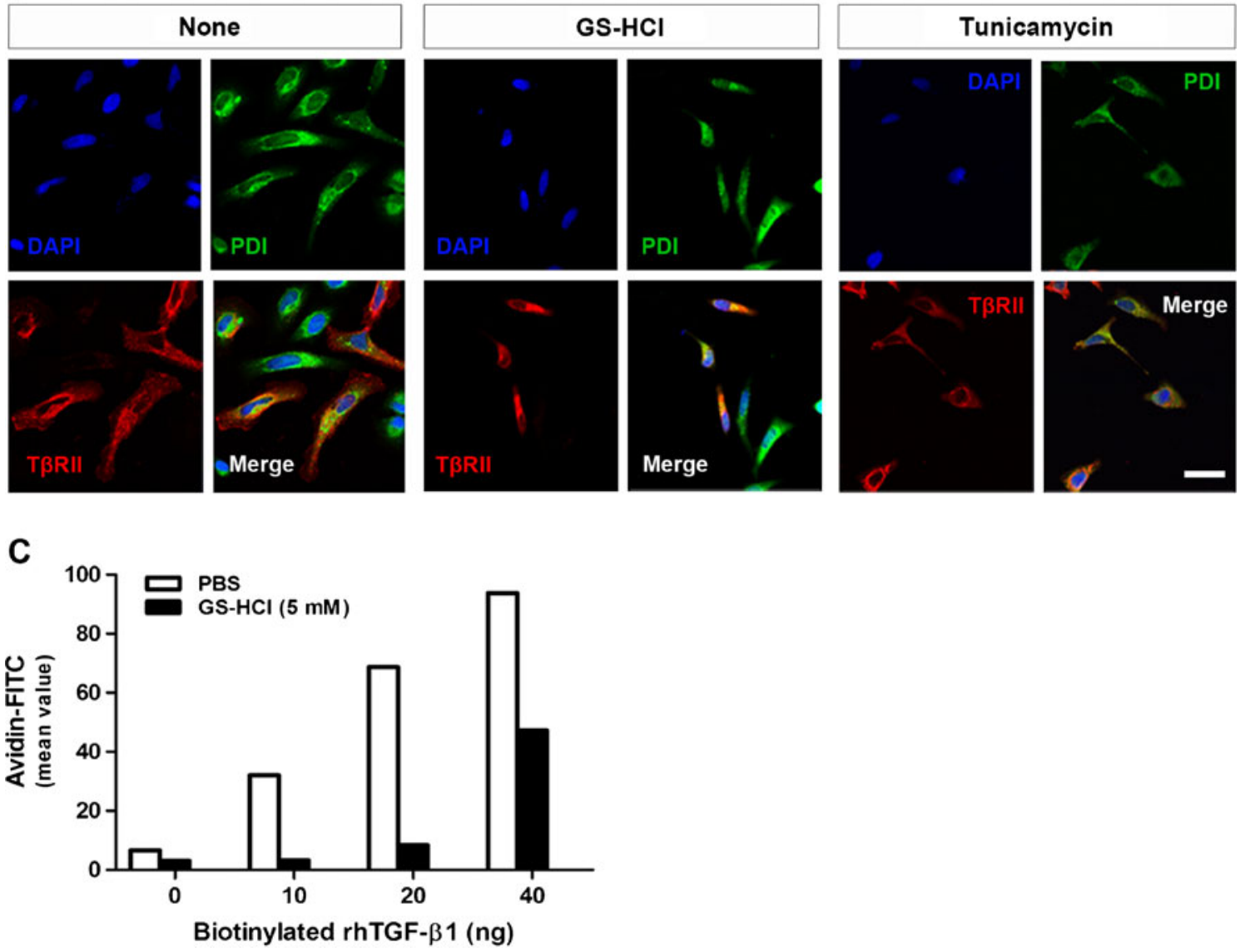

Fig. 6 GS-HCl-induced inhibition of T $\beta$ RII $N$-glycosylation hinders cell surface transport of T $\beta$ RII and subsequent TGF- $\beta 1$-binding. a, b Immunofluorescence staining shows subcellular localization of T $\beta$ RII (Flag; red), a phalloidin (green), and b protein disulfide isomerase (PDI; green) in HeLa cells. Phalloidin enabled the observation of cellular morphology by staining actin filaments. PDI was used as an ER marker. $D A P I$, 4',6-diamidino-2-phenylindole, was used for nucleus staining (blue). Note that GS-HCl interrupts cell surface transport of T $\beta \mathrm{RII}$ and

T $\beta$ RII and TGF- $\beta 1$ in signal transduction (Fig. 6). Consequently, GS-HCl reduced $\mathrm{Smad} 2 / 3$ phosphorylation in renal epithelial cells and UUO kidneys (Figs. 4 and 5). Taken

leads to the predominant accumulation of T $\beta$ RII in the cytosol. Bar= $50 \mu \mathrm{m}$. c Representative flow cytometric analysis of receptor density for recombinant human TGF- $\beta 1(r h T G F-\beta 1)$ at the cell surface. Various amounts of biotinylated TGF- $\beta 1(0-40 \mathrm{ng})$ were added to $1 \times 10^{5} \mathrm{HKC}$ 8 cells treated with or without GS-HCl $(5 \mathrm{mM}$ for $36 \mathrm{~h})$. The numbers of biotinylated TGF- $\beta 1$-bound T $\beta$ RII were quantified using rhTGF- $\beta 1$. Note that GS-HCl suppresses TGF- $\beta 1$ binding to T $\beta$ RII

together, our data demonstrate that GS-HCl-induced inhibition of T $\beta$ RII $N$-glycosylation effectively suppresses TGF- $\beta$ signaling. 
$N$-glycosylation, a form of posttranslational modification that attaches glycans to proteins or lipids, serves various functions, including protein stability, proper folding, localization, and ligand-receptor interactions [24, 28, 29]. Particularly, studies reveal that $\mathrm{N}$-glycosylation plays an important role in cell surface trafficking of membrane proteins, including CRFR1 [30] and dopamine transporter [31]. Defective $N$-glycosylation of these proteins is implicated in intracellular retention, thereby leading to reduced stimulation potency in response to the ligand. This phenomenon was also reproduced in our previous study showing that defective $N$-glycosylation, achieved by sitedirected mutagenesis or tunicamycin treatment, attenuated successful T $\beta$ RII cell surface transport, leading to decreased ligand-binding affinity [16]. The finding in the present study that GS-HCl is involved in impeding this function of $\mathrm{N}$-glycosylation is therefore noteworthy in the regulation of signaling pathway. Furthermore, in addition to TGF- $\beta 1$, fibrogenic factors, including EGF, PDGF, FGF2, CTGF, and AngII, integrate fibrogenic signals and coordinate ECM production [5]. And, their respective receptors, such as EGFR [32], FGFR1 [33], $\beta 1$ intergrin [34], and AT1a AngII receptor [35], are known to be $N$ glycosylated. Therefore, investigating the effect of GS-HCl on $\mathrm{N}$-glycosylation of these receptors and subsequent signaling pathways will establish the precise mechanism of $\mathrm{GS}-\mathrm{HCl}$ on renal fibrosis.

It has been proven that humans tolerate at least $184 \mathrm{mg} / \mathrm{kg} /$ day of GS-HCl intake without documented toxicity or side effects. It is also reported that large doses of glucosamine supplementation neither cause glucose intolerance nor affect glucose metabolism [1]. Therefore, glucosamine supplements possess an advantage in its application as a therapeutic agent for preventing fibrotic kidney dysfunction. However, more precise mechanisms and the therapeutic efficacy against renal fibrosis should be scrutinized in further studies.

In conclusion, we have herein demonstrated for the first time that GS-HCl-induced suppression of TGF- $\beta$ signaling by inhibiting $N$-glycosylation of T $\beta$ RII significantly reduces renal fibrosis. This was corroborated by the observations that the expression of key components involved in renal fibrosis was attenuated by $\mathrm{GS}-\mathrm{HCl}$ in vitro and in vivo. All together, these data provide a strong evidence for the clinical efficacy of glucosamine supplements in the prevention of fibrotic kidney diseases.

Acknowledgments This work was supported by a National Research Foundation grant of Korea (2009-0081756 and 2011-0014281) funded by the Korea government.

Conflict of interest All the authors declared no competing interests.
Open Access This article is distributed under the terms of the Creative Commons Attribution License which permits any use, distribution, and reproduction in any medium, provided the original author(s) and the source are credited.

\section{References}

1. Anderson JW, Nicolosi RJ, Borzelleca JF (2005) Glucosamine effects in humans: a review of effects on glucose metabolism, side effects, safety considerations and efficacy. Food and chemical toxicology: an international journal published for the British Industrial Biological Research Association 43:187-201. DOI 10.1016/j.fct.2004.11.006

2. Reginster JY, Deroisy R, Rovati LC, Lee RL, Lejeune E, Bruyere O, Giacovelli G, Henrotin Y, Dacre JE, Gossett C (2001) Long-term effects of glucosamine sulphate on osteoarthritis progression: a randomised, placebo-controlled clinical trial. Lancet 357:251-256. doi:10.1016/s0140-6736(00)03610-2

3. Wu YL, Kou YR, Ou HL, Chien HY, Chuang KH, Liu HH, Lee TS, Tsai CY, Lu ML (2010) Glucosamine regulation of LPS-mediated inflammation in human bronchial epithelial cells. Eur j pharmacol 635:219-226. doi:10.1016/j.ejphar.2010.02.044

4. Hwang SY, Shin JH, Hwang JS, Kim SY, Shin JA, Oh ES, Oh S, Kim JB, Lee JK, Han IO (2010) Glucosamine exerts a neuroprotective effect via suppression of inflammation in rat brain ischemia/ reperfusion injury. Glia 58:1881-1892. doi:10.1002/glia.21058

5. Liu Y (2011) Cellular and molecular mechanisms of renal fibrosis. Nat rev Nephrol 7:684-696. doi:10.1038/nrneph.2011.149

6. Garcia-Sanchez O, Lopez-Hernandez FJ, Lopez-Novoa JM (2010) An integrative view on the role of TGF-beta in the progressive tubular deletion associated with chronic kidney disease. Kidney int 77:950-955. doi:10.1038/ki.2010.88

7. Massague J, Blain SW, Lo RS (2000) TGFbeta signaling in growth control, cancer, and heritable disorders. Cell 103:295-309

8. Liu Y (2004) Epithelial to mesenchymal transition in renal fibrogenesis: pathologic significance, molecular mechanism, and therapeutic intervention. J Am Soc Nephrol : JASN 15:1-12

9. Boor P, Ostendorf T, Floege J (2010) Renal fibrosis: novel insights into mechanisms and therapeutic targets. Nat rev Nephrol 6:643-656. doi:10.1038/nrneph.2010.120

10. Petersen M, Thorikay M, Deckers M, van Dinther M, Grygielko ET, Gellibert F, de Gouville AC, Huet S, ten Dijke P, Laping NJ (2008) Oral administration of GW788388, an inhibitor of TGF-beta type I and II receptor kinases, decreases renal fibrosis. Kidney int 73:705715. doi:10.1038/sj.ki.5002717

11. Moon JA, Kim HT, Cho IS, Sheen YY, Kim DK (2006) IN-1130, a novel transforming growth factor-beta type I receptor kinase (ALK5) inhibitor, suppresses renal fibrosis in obstructive nephropathy. Kidney int 70:1234-1243. doi:10.1038/sj.ki.5001775

12. Border WA, Okuda S, Languino LR, Sporn MB, Ruoslahti E (1990) Suppression of experimental glomerulonephritis by antiserum against transforming growth factor beta 1. Nature 346:371-374. doi:10. 1038/346371 a0

13. Ma LJ, Jha S, Ling H, Pozzi A, Ledbetter S, Fogo AB (2004) Divergent effects of low versus high dose anti-TGF-beta antibody in puromycin aminonucleoside nephropathy in rats. Kidney int 65 : 106-115. doi:10.1111/j.1523-1755.2004.00381.x

14. Kang JS, Liu C, Derynck R (2009) New regulatory mechanisms of TGF-beta receptor function. Trends cell biol 19:385-394. doi:10. 1016/j.tcb.2009.05.008

15. Shi Y, Massague J (2003) Mechanisms of TGF-beta signaling from cell membrane to the nucleus. Cell 113:685-700

16. Kim YW, Park J, Lee HJ, Lee SY, Kim SJ (2012) TGF-beta sensitivity is determined by N-linked glycosylation of the type II TGF-beta receptor. Biochem j 445:403-411. doi:10.1042/bj20111923 
17. Liang CM, Tai MC, Chang YH, Chen YH, Chen CL, Chien MW, Chen JT (2010) Glucosamine inhibits epidermal growth factorinduced proliferation and cell-cycle progression in retinal pigment epithelial cells. Mol vis 16:2559-2571

18. Jang BC, Sung SH, Park JG, Park JW, Bae JH, Shin DH, Park GY, Han SB, Suh SI (2007) Glucosamine hydrochloride specifically inhibits COX-2 by preventing COX-2 N-glycosylation and by increasing COX-2 protein turnover in a proteasome-dependent manner. J biol chem 282:27622-27632. doi:10.1074/jbc.M610778200

19. Zhang Y, Kong J, Deb DK, Chang A, Li YC (2010) Vitamin D receptor attenuates renal fibrosis by suppressing the reninangiotensin system. J Am Soc Nephrol: JASN 21:966-973. doi:10. 1681/asn.2009080872

20. Racusen LC, Solez K, Colvin RB, Bonsib SM, Castro MC, Cavallo T, Croker BP, Demetris AJ, Drachenberg CB, Fogo AB et al (1999) The Banff 97 working classification of renal allograft pathology. Kidney int 55:713-723. doi:10.1046/j.1523-1755.1999.00299.x

21. Qiu W, Avramoglu RK, Rutledge AC, Tsai J, Adeli K (2006) Mechanisms of glucosamine-induced suppression of the hepatic assembly and secretion of apolipoprotein B-100-containing lipoproteins. J lipid res 47:1749-1761. doi:10.1194/jlr.M500363-JLR200

22. McCulloch DR, Wylie JD, Longpre JM, Leduc R, Apte SS (2010) $10 \mathrm{Mm}$ glucosamine prevents activation of proADAMTS5 (aggrecanase-2) in transfected cells by interference with posttranslational modification of furin. Osteoarthr cartil / OARS, Osteoarthr Res Soc 18:455-463. doi:10.1016/j.joca.2009.10.014

23. Chen CL, Liang CM, Chen YH, Tai MC, Lu DW, Chen JT (2012) Glucosamine modulates TNF-alpha-induced ICAM-1 expression and function through O-linked and N-linked glycosylation in human retinal pigment epithelial cells. Invest ophthalmol vis sci 53:22812291. doi:10.1167/iovs.11-9291

24. Petrecca K, Atanasiu R, Akhavan A, Shrier A (1999) N-linked glycosylation sites determine HERG channel surface membrane expression. J physiol 515(Pt 1):41-48

25. Bottinger EP, Bitzer M (2002) TGF-beta signaling in renal disease. J Am Soc Nephrol: JASN 13:2600-2610
26. Yokoi H, Mukoyama M, Sugawara A, Mori K, Nagae T, Makino H, Suganami T, Yahata K, Fujinaga Y, Tanaka I et al (2002) Role of connective tissue growth factor in fibronectin expression and tubulointerstitial fibrosis. Am $\mathrm{j}$ physiol Ren physiol 282:F933-F942

27. Wells RG, Yankelev H, Lin HY, Lodish HF (1997) Biosynthesis of the type I and type II TGF-beta receptors. Implications for complex formation. J biol che 272:11444-11451

28. Velan B, Kronman C, Ordentlich A, Flashner Y, Leitner M, Cohen S, Shafferman A (1993) N-glycosylation of human acetylcholinesterase: effects on activity, stability and biosynthesis. Biochem j 296(Pt 3):649-656

29. Helenius A (1994) How N-linked oligosaccharides affect glycoprotein folding in the endoplasmic reticulum. Mol biol cell 5:253-265

30. Assil IQ, Abou-Samra AB (2001) N-glycosylation of CRF receptor type 1 is important for its ligand-specific interaction. Am $\mathrm{j}$ physiol Endocrinol metab 281:E1015-E1021

31. Li LB, Chen N, Ramamoorthy S, Chi L, Cui XN, Wang LC, Reith ME (2004) The role of N-glycosylation in function and surface trafficking of the human dopamine transporter. J biol chem 279: 21012-21020. doi:10.1074/jbc.M311972200

32. Chen J, Chen JK, Nagai K, Plieth D, Tan M, Lee TC, Threadgill DW, Neilson EG, Harris RC (2012) EGFR signaling promotes TGFbetadependent renal fibrosis. J Am Soc Nephrol: JASN 23:215-224

33. Duchesne L, Tissot B, Rudd TR, Dell A, Fernig DG (2006) Nglycosylation of fibroblast growth factor receptor 1 regulates ligand and heparan sulfate co-receptor binding. J biol chem 281:2717827189

34. Guo HB, Lee I, Kamar M, Akiyama SK, Pierce M (2002) Aberrant $\mathrm{N}$-glycosylation of beta1 integrin causes reduced alpha5beta1 integrin clustering and stimulates cell migration. Cancer Res 62: $6837-6845$

35. Deslauriers B, Ponce C, Lombard C, Larguier R, Bonnafous JC, Marie J (1999) N-glycosylation requirements for the ATla angiotensin II receptor delivery to the plasma membrane. Biochem $\mathrm{j} 339: 397-405$ 